\title{
Hermenêutica e Interpretação: Um Estudo dos Cânones de Carlos Maximiliano
}

\section{Elena de Lemos Pinto Aydos}

\section{INTRODUÇÃO}

O presente estudo versa sobre hermenêutica e interpretação da Constituição, tendo por objetivo apresentar uma visão contemporânea da aplicação dos cânones prudenciais, elaborados por Carlos Maximiliano, ao sistema jurídico-constitucional introduzido em 1988.

Dividiu-se o trabalho em dois capítulos. No primeiro, foram trabalhados os conceitos de interpretação e hermenêutica, a sua importância e relaçãa com a atividade de aplicação do direito. Em seguida, foram apresentadas algumas peculiaridades da Constituição frente às demais leis. Justificou-se o cuidado Que deve o intérprete tomar ao aplicar regras gerais de interpretação às normas constitucionais e defendeu-se a utilização de regras específicas para a interpretação da Constituição. Finalmente, fez-se uma abordagem em torno dos Quatro métodos clássicos de interpretação comumente apontados pela doutrina, ou seja, o método gramatical, histórico, sistemático e teleológico, sintetizando os fundamentos e aplicação de cada um.

No segundo capítulo, partiu-se ao estudo dos cânones de Carlos Maximiliano, propriamente ditos. Para tanto, buscou-se relacionar e sistematizar os enunciados prudenciais deservolvidos pelo autor, com os seguintes princípios de interpretação constitucional, praticados pela doutrina contemporânea: Supremacia da Constituição, Interpretação. Presunção de Constitucionalidade das Leis e dos Atos do Poder Público, Interpretação Conforme, Unidade da Constituição e Máxima Efetividade, tomando por base a obra de Luís Roberto Barroso.

Trata-se de uma visão alternativa, Que busca uma sistematização dos cânones de Maximiliano, relacionando-os com os ensinamentos de alguns autores contemporâneos: uma contribuição à disciplina hermenêutica na interpretação constitucional. 


\section{HERMENÊUTICA E INTERPRETAÇÃO}

\subsection{Conceito e Importância da Interpretação}

Interpretar significa atribuir o conteúdo, sentido e alcance de um texto normativo, visando a sua aplicação a um caso concreto' : Não se concebe a idéia de Que o intérprete exerça um papel neutro e burocrático, de mera descrição do significado objetivo de um dispositivo ${ }^{2}$, sendo forçoso reconhecer que o processo de interpretação implica na compreensão, fundamentação e reconstrução (visão triádica da interpretação) ${ }^{3}$ de significados, por meio de uma atuação positiva do intérprete, sendo inafastável o elemento essencialmente comunicativo dessa atividade 4 .

1. Adotarse aqui a idéia de que "Normas não são textos nem o conjunto deles, mas os sentidos construídos a partir da interpretação sistemática de textos normativos. Daí a se afirmar que os dispositivos se constituem no objeto da interpretaçăo; e as normas, no seu resultado". In: ÁVILA, Humberto. Teoria dos Princípios - da definição à aplicação dos princípios jurídicos. 3a ed. São Paulo: Malheiros, 2004, p. 22.

2 Tendência que predominou na sociedade liberal desenvolvida a partir do século XVII, fundamentada principalmente na teoria política da separação dos Poderes de Montesquieu e no ideal Hobbesiano de segurança jurídica. No mesmo sentido: AYDOS, Elena de Lemos Pinto. Aspectos Atuais do Direito de Marca: A regulamentação da Marca e sua Proteção Através das Técnicas Diferenciadas de Tutela. Trabaiho de conclusão de Curso de Graduação. PUCRS. Porto Alegre, 2003, p. 126.

Nas palavfas de Montesquieu: "Poderia acontecer que a lei, que é ao mesmo tempo clarividente e ccga, fosse em certos casos muito rigorosa. Porém, os juizes da nação nảo são, conforme já dissemos, mais que a boca Que pronuncia as palavras da lei, seres inanimados que desta lei não podem moderar nem a força nem o rigor" In: MONTESQuiteU. Do Espírito das Leis. Coleção Obra Prima de Cada Autor. Săo Paulo: Martin Claret, 2002, p. 172.

Pode-se verificar a influência desse ideal na obra de Maximiliano, Que descreve a atividade de interpretar como sendo "... extrair, de frase, sentença ou norma, tudo o que na mesma se contém", ainda que adiante tenha que admitir que "O intérprete é o renovador inteligente e cauto, o sociólogo do Direito. O seu trabalho rejuvenesce e fecunda a fórmuta prematuramente decrépita, e atua como elemento integrador e complementar da própria lei escrita. Esta é a estática, e a fundação interpretativa, a dinâmica do Direito". MAXIMILIANO, Carlos. Hermenêutica e Aplicação do Direito. $19^{a}$ ed. Rìo de laneiro: Forense, 2005, p. 7/10.

3 "Na epistemologia de síntese, a linguagem - Que é, também, sede de entendimento e do conhecimento - pressupõe três determinações funcionais do agir e do fazer comunicativos, Quc são correlatas às dimensões funcionais do modelo habermas/parsoniano de comunicação, mas que, para maior precisão conceitual e para a adequạda derivação de todas as suas implicaçōes, convencionamos designar como as funçōes: da fundamentaçáo transcendental do entendimento dos seus enunciados; da compreensăo participativa do discurso Que os integram; c da reconstrução leórica do significado Que denotam" In: AYDOS, Eduardo Dutra. A Planície de Alétheia - Contribuição para a (re)construçăo teórica de uma epistemologia de síntese. Porto Alegre: UFRGS, 2002, p. 38.

4 O aspecto comunicativo e subjetivista pressupõe uma verdadeira relação entre o sujeito e o objeto da interpretação, numa ilimitada comunidade de comunicação mediada por signos. Esse caráter é apontado pela doutrina, Que utiliza freqücntemente as expressóes "volitivo" ou "voluntarista". Não obs lante, tem-se Que tais termos poderiam transparecer a falsa idéia de que há um "tivre-arbítrio" na atividade interpretativa, o Que năo se admite, na medida em que o intérprete estará sempre adstrito aos limites da fundamentaçäo, da aplicação de métodos jurídicos, bem como dos limites da própria linguagem do texto normativo. 
Cumpre esclarecer que o Direito se manifesta através da linguagem, sendo que a sua representação sígnica dá-se pelo texto ${ }^{5}$. Sabe-se que todo o signo é composto por três elementos, onde um deles inevitavelmente, e por definição, oferece resistência ao entendimento (apreensão imediata) ${ }^{6}$. Disso se extrai que a exigência de interpretação, na atribuição de um fundamento ao objeto Que se representa, é um atributo intrínseco do próprio signo ${ }^{7}$.

É assim Que se pode afirmar Que uma primeira dificuldade de determinação do sentido e alcance de um dispositivo normativo, surge do fato que as palavras, de modo geral, são imprecisas e ambíguas, impondo-se ao intérprete uma escolha preliminar dentre os diversos significados possíveis ${ }^{8}$.

Não bastassem as imprecisões semânticas, há ainda outro fator determinante da idéia de imprescindibilidade da atividade interpretativa, que consiste no fato de Que a interpretação do texto normativo visa sempre a sua aplicação a um caso concreto ${ }^{9}$. A aplicação consiste no processo de incidência da norma - considerada essa como o significado do texto normativo (plano do conteúdo ${ }^{19}$ ), produto do processo de interpretação - ao fato jurídico, tambérn conhecido como processo de subsunção da norma. Acontece Que, tanto Quanto a

5. A prova palpável de que o direito é texto está em que todo ordenamento jurídico é suscetível de ser escrito, isto é, de ser convertido em palavras. Até mesmo as normas que não nascem escritas, aquelas que são consuetudinárias, têm essa característica. O direito é linguagem no sentido de que sua forma de expressão consubstancial é a linguagem verbalizada suscetível de ser escrita. Isto aparece especialmente no direito moderno, Que já nasce escrito". In: ROBLES, Gregório. O Direito Como Texto: Quatro estudos se teoria comunicacional do direito. Barueri, SP: Manole, 2005, p. 2. Ver, ainda, CARVALHO, Paulo de Barros, Curso de Direito Tributário. 16a ed. Săo Paulo: Saraiva, 2004, p. 1/18.

- Săo três conceitos propostos por Peirce: "Originalidade é ser tal como aquele ser é, independentemente de Qualeuer outra coisa. Obsistência (sugerindo obviar, objeto, obstinadod, obstáculo, insistência, resistência, etc.) é aquilo no Quc a secundidade difere da primeiridade; ou é aQuele elemento que, tomado em conexão com a Originalidade, faz de uma coisa aeuilo que uma outra a obriga a ser. Transuasäo (sugerindo translação, transaçăo, transfusão, transcendental, etc.) é mediação, ou a modificação da primeiridade e da secundidade pela terceiridade, tomada à parte da secundidade e da primeiridade; ou, é ser enquanto cria Obsistência". In: PEiRCE, Charles S. Semiótica. São Paulo: Perspectiva, 1977, p. 27.

7 "Um signo, ou representàmen, é aquilo Que, sob certo aspecto ou modo, represcnta algo para alguém. Dirige-se a alguém, isto é, cria na mente dessa pessoa, um signo equivalente, ou talvez um signo mais desenvolvido. Ao signo assim criado denomino interpretante do primeiro signo. (...)". In: PEIRCE, Charles S. Semiótica. São Paulo: Perspectiva, 1977, p. 46.

8 BASTOS, Celso Ribeiro. Hermenêutica e Interpretação Constitucional. $3^{\hat{a}}$ ed. Säo Paulo: Celso Bastos, 2002, p. 41.

- BASTOS, Celso Ribeiro. Hermenêutica e Interpretação Constitucional. $3^{\text {a }}$ ed. São Paulo: Celso Bastos, 2002, p. 29; BARROSO, Luís Roberto. Interpretação e Aplicação da Constituição. $3^{\text {a }}$ ed. São Paulo: Saraiva, 1999, p. 103.

10 FERRAGUT, Maria Rita. Crédito Tributário, Lançamento e Espécies de Lançamento Tributário. In: SANTt, Eurico Marcos Diniz de. (Coord.). Curso de Especialização em Direito Tributário - Homenagem a Paulo de Barros Carvalho. Capítulo Il. Rio de laneiro: Forense, 2004. 
aplicação da lei pressupõe necessariamente uma atividade interpretativa, também não é possivel conceber a interpretação de texto normativo sem Que se tenha em mente a sua incidência a um certo fato hipotético".

$\mathrm{Na}$ medida em Que as leis são formuladas de forma genérica e abstrata, visando abarcar o maior número de eventos hipotéticos possíveis ${ }^{12}$, o jurista e o cientista do direito ${ }^{13}$, ao interpretar a lei, desenvolvem o caminho inverso, delimitando, construindo, reconstruindo

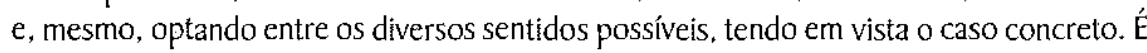
nesse momento, de concretização de conceitos genéricos e ambíguos, Que surgem as principais dificuldades e a ineuestionável necessidade de interpretação da lei ${ }^{14}$.

Portanto, todo o dispositivo normativo, seja constitucional ou infra-constitucional, precisa ser interpretado, não mais podendo ser aceito como verdadeiro o brocardo jurídico in claris cessat interpretatio ${ }^{15}$. Ainda cue o texto da norma seja de pouca complexidade e suas palavras aparentemente não comportem ambigüidades, para Que o juiz conclua pela sua clareza e precisão, necessariamente deverá realizar uma atividade de interpretação, pois por certo Que as normas não se auto-intitulam como sendo claras ou não ${ }^{16}$. Essa concepção tem suas origens no direito romano, podendo-se encontrar passagens no Digesto ${ }^{17}$ onde é destacada a importância da interpretação.

"BASTOS, Celso Ribeiro. Hermenêutica e Interpretação Constituclonal. $3^{a}$ ed. São Paulo: Celso Bastos, 2002, p. 40.

12 BARROSO, Luís Roberto. Interpretação e Aplicaçăo da Constituição. $3^{a}$ ed. São Paulo: Saraiva, 1999 , p. 41.

13 "Os juristas năo se limitam a ler o texto juridico com olhos de profissionais capazes de entender completamente seu sentido; são eles, além disso, os encarregados de interpretar as normas. A interpretação das normas cabe especialmente a determinados juristas: aqueles Que ocupam órgãos de decisăo (como os juizes) e os Que se dedicam à ciência do direito (os cientistas do direito)". In: ROBLES, Gregório. O Direito Como Texto: Quatro estudos se teoria comunicacional do direito. Barueri, SP: Manole, 2005, p. 53.

${ }^{14}$ MAXIMILLANO, Carlos. Hermenêutica e Aplicaçäo do Direito. $19^{a}$ ed. Rio de laneiro: Forense, 2005, p. 11.

15 "Disposiçóes claras näo comportam interpretação - Lei clara não carece de interpretaçăo - Em sendo claro o texto, näo se admite pesquisa da vontade - famoso dogma axiomático, dominador absoluto dos pretórios há meio século; alîrmativa sem nenhum valor cientílico, ante as idéias triunfantes na atualidade" MAXIMILIANO, Carlos. Hermenêutica e Aplicação do Direito. 19a ed. Rio de Janeiro: Forense, 2005, p 27.

is Nesse mesmo sentido: MAXIMILIANO, Carlos. Hermenêutica e Aplicação do Direito. $19^{a}$ ed. Río de Janeiro: Forense, 2005, p. 7/8; BASTOS. Celso Ribeiro. Hermenêutica e Interpretação Constitucional. $3^{\not a}$ ed. São Paulo: Celso Bastos, 2002, p. 4l/46; BONAVIDES, Paulo. Direito Consltucional. Rio de Janeiro: Forense, 1980, p. 268; BARROSO, Luís Roberto, Intcrpretação e Aplicação da Constituição. 3a ed. Säo Paulo: Saraiva, 1999. p. 105/106.

17 "Neque leges neque senatusconsulta ita scribi possunt, ut omnes casus qui quandoque inciderint comprehendantur, sed sufficit ea quae perumque accidunt contineri - Nem as leis nem os senałus-consultos podem escrever de tal maneira que todos os casos, seja Qual for o tempo em que ocorram, sejan compreendidos pela norma, mas basta que contemplem aqueles que na maior parte das vezes ocorrem" (Oigesto, liv. I, tít. 3 frag. 10); "Et ideo de his, Quae primo constituuntur, aut interpretatione aut constitutione optimi principis certius statuedum est E por isso, Quanto àQuelas que se constituem pela ptimeira vez, hão de ser fixadas com mais certeza ou por meio da interpretaçăo ou por de uma constituição do ótimo príncipe" (Digesto, liv. 1, tít. 3, frag. 11); "Scire leges non hoc est verba earum tenere, sed vim ac potestatem - Conhecer as leis não é reter as palavras delas, mas a sua força e majestade" (Digesto, LIV. I, TíT. 3, FRAG. 17). In: Digesto de Justiniano, livro I. Traduçăo de Hélcio Maciel França Madeira. $2^{a}$ ed. São Paulo: RT, 2000. 
O caráter personalíssimo da atividade interpretativa não pode, entretanto, ser confundido com o argumento de autoridade. Ao contrário, a concepção Que se tem de interferência do intérprete no resultado final - a atribuição do sentido e alcance da norma leva em conta a possibilidade de escolha dentre diferentes métodos ou critérios jurídicos. passíveis de serem utilizados na atividade interpretativa; e não a ausência destes. Prova disso é a exigência nas sociedades contemporâneas de que as decisões judiciais sejam justificadas de forma jurídico-normativa, ou seja, fundamentadas em razões que assegurem a "justiça de acordo com o direito" ${ }^{18}$. Não obstante, não é estranho, sendo até mesmo previsivel, Que na interpretação de um mesmo texto normativo, se possa obter resultados diversos, em função da influência dos aspectos da personalidade de cada intérprete ${ }^{19}$.

O intérprete terá de identificar, dentre as diversas normas do ordenamento jurídico, aQuela aplicável à hipótese em apreço, sendo Que muitas vezes poderá se deparar com mais de uma norma válida, conduzindo a resultados diversos. Nesse momento é Que tem lugar a atividade interpretativa, Quando passarão a ser utilizados princípios e critérios de hermenêutica, para definir o conteúdo do texto normativo (resultando na norma propriamente dita), então, determinar a sua aplicação ou não ao caso concreto ${ }^{20}$.

Nas palavras de Maximiliano, Que refletem o momento expansionista da modernidade cientificista, "a hermenêutica é a teoria científica da arte de interpretar" ${ }^{21}$. Uma visão mais consentânea com a crise paradigmática da pós-modernidade, haveria de postular que a hermenêutica é a disciplina do conhecimento Que se preocupa em refletir, programar e verificar a eficácia, de forma lógica e sistemática, dos métodos e critérios Que serão utilizados, concretamente, na atividade de interpretação.

18 MACCORMICK, Neil. Legal Reasoning and Legal Theory. Oxford: Clarendon Press, 1978 apud POGREBINSCHI, Thamy. Problema da Justificação no Direito: Algumas Notas sobre Argumentaçăo e Interpretação. In: MAIA, A. C.; MELO, C.C.; CITTADINO. G; POGREBINSCHI, T. (Org.). Perspectivas Aluais da Filosofia do Direito. Rio de laneiro: Lumen Juris, 2005, p. 449/470.

19 BASTOS, Celso Ribeiro. Hermenêutica e Interpretação Constitucional. $3^{\text {a }}$ ed. São Paulo: Celso Bastos, 2002, p. 47/48;

20 Conforme cnsinamento de Celso Ribciro Bastos, não compreende a atividade interpretativa a simples verfficação sistemática da validade de uma lei, considerando-se critérios como o da hicrarquia, temporal e de especialidade. Estes podem ser mecanicamente aplicados e resultan da própria condiçáo do ordenamento jurídico enquanto sistema. In: BASTOS. Celso Ribeiro. Hermenêutica e Interpretação Constitucional. $3^{a}$ ed. São Paulo: Celso Bastos, 2002, p. 48/49.

21 MAXIMILIANO, Carlos. Hcrmenêutica e Aplicaçăo do Direito. 19a ed. Rio de laneiro: Forense, 2005, p 1/4; BASTOS, Celso Ribeiro. Hermenêutica e Interpretação Constilucional. $3^{\text {a }}$ ed. Săo Paulo: Celso Bastos, 2002, p. 28/36. 


\section{I.2 A Interpretação da Constituição}

A Constituição, tal Qual acontece com as leis infra-constitucionais, precisa ser interpretada, sendo Que as Questões pertinentes à definição e importância da atividade interpretativa de modo geral, abordadas no item anterior, aplicam-se também à atividade de interpretação constitucional. Todavia, as normas formal e materialmente constitucionais apresentam peculiaridades Que as diferenciam das demais, o Que determina que o intérprete adote, além dos métodos de hermenêutica geral, técnicas especiais de hermenêutica fundamental ${ }^{22}$.

Outrossim, devido ao caráter aberto das normas constitucionais, Que freqüentemente se apresentam na forma de princípios ou normas programáticas, há ainda a ocorrência de uma nova atividade intelectiva. própria do processo de interpretação da Lei Maior, Que consiste na construção normativa ${ }^{23}$. A idéia de Que o intérprete constitucional possa exercer uma atividade construtiva, no sentido de realmente criar uma norma individual e concreta - efetivamente ultrapassando a mera atribuição de sentido e alcance a um texto normativo - é concepção desenvolvida a partir do pós-positivismo, cuja metodologia jurídica admite que a norma a ser aplicada ao caso concreto "é também produto da razão prática e não só objeto da razão teórica" ${ }^{24}$.

Além do aspecto de generalidade, conforme ensina Luís Roberto Barroso, são características distintivas das normas constitucionais: a superioridade hierárouica, a natureza da linguagem, o conteúdo específico e o caráter político ${ }^{25}$.

A superioridade hierárquica, abordada por Celso Ribeiro Bastos como "inicialidade fundante das normas constitucionais" ${ }^{26}$, implica na exigência de Que todas as demais leis estejam em conformidade com a Lei Maior. Esse caráter autônomo e hierarQuicamente superior do Direito Constituicional foi determinante para a adoção de uma jurisdição

${ }^{22}$ MAXIMillaNO, Carlos. Hermenêutica e Apticação do Direito. $19^{a}$ ed. Rio de laneiro: Forense, 2005, p 248: BARROSO, Luís Roberto. Interpretação e Aplicação da Constituição. $3^{a}$ ed. Săo Paulo: Saraiva, 1999, p. 103/112; BASTOS, Celso Ribeiro. Hermenêtica e Interpretação Constitucional. $3^{\text {a }}$ ed. São Paulo: Celso Bastos, 2002, p. 105/[21;

${ }^{23}$ NETO, Cláudio Pereira de Souza. A interpretação Constitucional Contemporânea entre o Construtivismo e o Pragmatismo. In: MAIA, A. C.; MELO, C.C.; CITTADINO. G; POGREBINSCHI, T. (Org.). Perspectivas Atuais da Filosofia do Direito. Rio de Janeiro: Lumen luris, 2005, p. 475/497; BARROSO, Luís Roberto. Interpretação e Aplicação da Constituição. $3^{a}$ ed. São Paulo: Saraiva, 1999, p. 103.

${ }^{24}$ NETO, Cláudio Pereira de Souza. A Interpretaçäo Constitucional Contemporânea entre o Construtivismo e o Pragmatismo. in: MAIA, A. C.; MELO, C.C.; CITTADINO. G; POGREBINSCHI, T. (Org.). Perspectivas Atuais da Filosofia do Direito. Rio de laneiro: Lumen Juris, 2005, p. 477/478. Uma das conclusóes do autor é a c que "o positivismo normativista de Kelsen considerava que somente a atividade cognitiva podia ser racional. Por conta disso, o autor exclui a fazão prática da metodologia jurídica".

25 BARROSO, Luís Roberto. Interpretação e Aplicação da Constituição. $3^{a}$ ed. Săo Paulo: Saraiva, 1999, p. 107.

26 BASTOS, Celso Ribeiro. Hermenêutica e interpretação Constitucional. $3^{\text {a }}$ ed. São Paulo: Celso Bastos, 2002, p. 105/110. 
constitucional, Que só existiu efetivamente na Europa a partir do segundo pós-guerra, Quando a maioria dos ordenamentos jurídicos europeus adotou o Controle de Constitucionalidade abstrato, com sistema de jurisdiçôes distintas ${ }^{27}$. Consequentemente, se pode afirmar que a interpretação da Constituição assume uma dupla função, ou seja, proporcionar a aplicação direta da norma constitucional a um determinado Fato jurídico, ou ainda, exercer o exame e o controle acerca da constitucionalidade uma lej ${ }^{28}$.

Deve-se observar que a natureza hierárquica do sistema jurídico-constitucional, Que realça a superioridade da Lei Maior, é dotada de unicidade - estruturada de alto a baixo sendo defeso ao intérprete abstrair dessa condição própria. Disso resılta que a aplicação direta do texto constitucional não pode sobrepor-se e construir norma concreta aplicável ao caso específico, em contradição à legislação infra-constitucional. Nesses casos, será necessário, antes, a deslegitimação da norma pelo respectivo controle da constitucionalidade (aplicação dos princípios da unidade e da presunção de constitucionalidade das leis e dos atos do Poder Público, Que serão tratados detalhadamente no segundo capítulo deste trabalho).

A natureza da linguagem constitucional, por sua vez, imprime um caráter de maior abstração e abertura das normas, o Que decorre do fato de a Lei Maior conter. preponderantemente, normas principiológicas e normas de estrutura (também chamadas normas de organização ou indiretas) ${ }^{29}$. Disso resulta a necessidade de o intérprete fazer uso de técnicas de interpretação diferenciadas daquelas que usaria para interpretar as normas de conduta (caráter hipotético-condicional).

Quanto à Questão em torno do "conteúdo específico", Luiz Roberto Barroso referese ao fato de Que normalmente há a presença de normas programáticas na Constituição. Segundo o autor, essas normas não conferem direito subjetivo positivo, mas apenas "negativo", no sentido de poder se exigir do Estado Que não pratique atos contrários ao espírito da norma, ensejando métodos de hermenêutica especiais.

Finalmente, no que toca ao conteúdo político, esse é destacado por Maximiliano, Que afirma Que "o Direito Constitucional apoia-se no elemento político, essencialmente instável, a esta particularidade atende, com especial e constante cuidado, o exegeta. Naquele

27 Nos Estados Unidos, tem-se como marco do Controle de Constitucionalidade o caso Marbury vs. Madison, de 1.803. Aula ministrada pelo Professor Cezar Saldanha no dia 10/09/04, no Curso de Especialização em Direito do Estado da UFRGS.

${ }^{28}$ BARROSO, Luís Roberto. Interpretação e Aplicação da Constituição. $3^{a}$ ed. São Paulo: Saraiva, 1999, p. 106.

29 "Normas indiretas são as normas Que não contemplam diretamente a ação, mas se limitam a estabelecer elementos do sistema anteriores à regulação direta das ações. Criam as condições ou requisitos conforme os Quais a ação deve acontecer ou deve ser regulada. Criam os elementos espaciais e temporais do sistema, assim como os sujeitos e as capacidades ou competências destes. Expressam-se mediante o verbo ser, Que na norma tem caráter prescritivo, e não descritivo ou expositivo. Sendo suscetiveis de expressão pelo verbo ser, podem ser chamadas normas ônticas". ROBLES, Gregório. O Direito Como Texto: Quatro estudos se teoria comunicacional do direito. Barueri, SP: Manole, 2005, p. 15. 
departamento da ciência de Papiniano preponderam os valores jurídico-sociais. Devem as instituições ser entendidas e postas em função de modo Que correspondam às necessidades políticas, às tendências gerais da nacionalidade, à coordenação dos anelos elevados e justas aspirações do povo" ${ }^{30}$.

\subsection{Os Métodos CĹásicos de Interpretação}

A doutrina aponta Quatro métodos clássicos de hermenêutica, com caráter predominantemente teórico-jurídico, os Quais sejam, literal ou gramatical, histórico, lógico ou teleológico e sistemático. Os três primeiros métodos tem origem na obra de Savigny. fundador da Escola Histórica do Direito, sendo Que o método teleológico foi acrescentado posteriormente, cujo conteúdo foi desenvolvido principalmente por lhering, Heck e Geny ${ }^{34}$.

Esses critérios não consistem em normas jurídicas propriamente ditas, na medida em Que não possuem o elemento de coercibilidade. Não é obrigatório o uso de todos os métodos numa interpretação, ficando a critério do intérprete combinar dois ou mais métodos no exame de uma mesma situação hipotética. Além disso, não há hierarquia entre eles, muito embora a doutrina possa atribuir maior valor a determinados critérios de hermenêutica, em detrimento de outros, visando sempre acompanhar a evolução da sociedade e do direito ${ }^{32}$.

\subsubsection{Método Literal ou Gramatical}

O método gramatical é, normalmente, o primeiro a ser empregado no processo de interpretação. Consiste em buscar o significado semântico das palavras Que integram o texto normativo, aplicando-lhe as regras gramaticais e dirimindo as dúvidas em torno da literalidade do dispositivo ${ }^{33}$.

30 MAXimiliano, Carlos. Hermenêutica e Aplicação do Direito. 19a ed. Rio de janeiro: Forense, 2005, p 249.

3) BARROSO, Luís Roberto. Interpretaçäo e Aplicação da Constituição. $3^{a}$ ed. São Paulo: Saraiva, 1999, p. 124/143.

32 Luís Roberto Barroso aponta as seguintes diretrizes que devern ser adotadas no momento de escollia entre os diferentes métodos de hermenêutica: a) a interpretação gramatical não pode ser inteiramente desprezada; b) entre interpretações possíveis, deve-se optar pela Que conduza à compatibilização de uma norma com a Constituição; c) os métodos objetivos, como o sistemático e o teleológico têm preferência sobre o método subjetivo,ou seja, o histórico. Irt. BARROSO, Luís Roberto. Interpretação e Aplicação da Constituição. $3^{a}$ ed. São Paulo: Saraiva, 1999, p. $124 / 126$.

33 BASTOS, Celso Ribeiro. Hermenêutica e Interpretação Constitucional. $3^{a}$ ed. São Paulo: Celso Bastos, 2002, p. 57: BARROSO, Luís Roberto. Interpretação e Aplicaçăo da Constituição. $3^{a}$ ed. São Paulo: Saraiva, 1999, p. 126/136. 
Apesar de constituir o início do processo interpretativo, normalmente não será o único método utilizado pelo intérprete, sob pena de se obter um resultado pobre no seu conteúdo e desconforme com o sistema jurídico. Além disso, corre-se o risco, em uma interpretação estritamente literal, de incidir-se em erro grosseiro na exegese de um dispositivo, pois, não raras vezes, sāo encontradas impropriedades semânticas no texto normativo, comprovando pragmaticamente Que não é absoluta a clássica regra hermenêutica Que afirma Que a lei não utiliza palavras inúteis ${ }^{34}$. Paradoxalmente, não deve ser descartado o método gramatical, que constitui uma verdadeira limitação à atividade do intérprete. O jurista ou cientista do direito não podem, sob o argumento de empregar métodos mais importantes de hermenêutica, contrariar os limites estabelecidos pela linguagem empregada no texto normativo ${ }^{35}$.

\subsubsection{Método Histórico}

O intérprete, ao aplicar o método histórico, buscará informações a respeito da história da respectiva Constituição e de cada um de seus dispositivos, examinando as idéias dominantes à época da sua elaboração e qual a vontade histórica do legislador, para então chegar ao sentido e alcance do texto normativo para a sua aplicação ao caso concreto. Esse método orienta o intérprete para Que procure compreender as origens históricas das normas inseridas na Lei Maior, conhecer das suas causas e fins, comparar o texto vigente com o das Constituições Que o antecederam, inclusive verificando a influência sofrida pela Lei Fundamental de outros países ${ }^{36}$.

A interpretação histórica do texto normativo busca auxílio nos projetos e debates parlamentares, nas emendas, nos votos vencedores ou vencidos na Constituinte, as díscussóes à época na assembléia e, até mesmo, as revelações daQueles que presenciaram os trabalhos legislativos, ou seja, elementos Que apontem para o fim de cada preceito ${ }^{37}$. Carłos Maximiliano sugere, ainda, a utilização dos Anais e demais documentos contemporâneos, para facilitar a

${ }^{34}$ Não apenas palavras inúteis, como impropriedades ou desajustes semânticos săo encontrados freeüentemente nos textos normativos. Isso se explica facilmente en razão da própria natureza do processo legislativo, Que é realizado por representantes políticos, eleitos pelo povo, para cujo exercício de função nắo é exigido Qualquer conhecimento jurídico. Exemplo de impropriedade semântica pode ser encontrado no art. 150 do CTN, Quando o texto normativo chama de "lançamento por homologação" o ato pelo Qual o próprio contribuinte é responsável pela formação do enunciado concreto e individual constitutivo do crédito tributário. Tal expressão é equivocada e contraria o próprio sistema jurídico, na medida em Que o art. 142 do CTN define o lançamento como ato privativo da administração pública. Tal impropriedade semântica é responsável por infindáveis controvérsias em torno da natureza jurídica do ato previsto no art. 150 do CTN, justamente pela aplicação excłusiva, por alguns estudiosos do direito, do método gramatical de interpretação.

${ }_{35}$ Nesse mesmo sentido: MAXIMILIANO, Carlos. Comentários à Constituição. 1a ed. p. 93-94.

36 MAXIMiLIANO, Carlos. Comentários à Constituiçăo. I a ed. p. 91. No texto original, o autor faz referência à inlluência da Constituição do Império e da Constituição Norte-Americana sobre a Constituição de 1981: "Compare-se o texto vigente com o da Constituição Imperial e a dos Estados Unidos, não olvidando que o espírito destas duas, bem como os casos da Common Law e Equity, colhidos em classicos e brithantes commentarios, guiam o escrupuloso interprete da lei basica de 24 de Fevereiro".

37 Referindo-se à Constituiçẫo de 24 de fevereiro de 1891 , o autor ainda inclui como fonte para sua interprełação as "[...) idéias reveladas pela propaganda e insurreições republicanas, legislação imperial e tentativas da reforma respectiva [...]". 
averiguação do signilicado dos termos técnicos empregados no texto da legislação, segundo os conceitos aceitos na época ${ }^{38}$.

Assim como se deve aplicar com prudência o método gramatical, o mesmo se passa com o método histórico. Os motivos que impulsionaram os legisladores à época da votação do texto constitucional não vinculam o intérprete, Que poderá vir a aplicar exegese contrária, caso preponderem outros critérios de hermenêutica, mormente Quando a norma já data de época distante ${ }^{39}$. Nesse sentido, avalia Luís Roberto Barroso, Que a "patologia da interpretação histórica é o originalismo ...", referindo-se ao movimento americano que defende que a interpretação constitucional deve limitar-se exclusivamente à intenção original dos elaboradores da Constituição (the original intent). Os originalistas atacam as decisões da Suprema Corte Que afirmaram novos direitos às ninorias, argumentando Que os mesmos não eram vistumbrados à época da elaboração da Lei Maior ${ }^{40}$.

\subsubsection{Método Sistemático}

O método sistemático consiste em buscar o sentido do texto normativo tendo em vista o ordenamento jurídico como um todo. O intérprete não se limita à análise do dispositivo isolado, mas o situa no contexto normativo, de forma a manter a unidade do ordenamento jurídico ${ }^{41}$. Nas palavras de Celso Ribeiro Bastos, "destaca»se aqui a perspectiva sistêmica do ordenamento jurídico, bem como a sua unidade, procurando assim atingir uma visão global e estrutural da lei" ${ }^{42}$.

A Constituição, na Qualidade de "norma inicial fundante" (conforme conceito abordado supra) e, portanto, fundamento de validade de todo o ordenamento, tem papel fundamental na unidade do ordenamento jurídico. Além dessa noção de unidade externa, Luís Roberto Barroso ainda aponta o caráter de unidade interna da Constituição, Que leva necessariamente à análise de cada um de seus dispositivos de forma harmônica e sistemática com o plano geral da Constituição. O desdobramento do método sistemático, portanto, é o princípio da unidade da Constituição, Que será especificamente abordado no segundo capítulo desse trabalho ${ }^{43}$.

${ }^{3 B}$ MAXIMILIANO, Carlos. Comentários à Constituição. $1^{3}$ ed. p. 93.

39 MAXIMILIANO, Carlos. Comentários à Constituição. là ed. p. 91-93.

¿ BARROSO, Luís Roberto. Interpretação e Aplicação da Constituição. $3^{a}$ ed. São Paulo: Saraiva, 1999. p. $131 / 134$.

41 "A primeira e mais importante recomendação, nesse caso, é de que, em tese, Qualquer preceito isolado deve ser interpretado em harmonia com os princípios gerais do sistema, para que se preserve a coerência do todo. Portanto, nunca devemos isolar o preceito nem em seu contexto (a lei em tela, o código: penal, civil etc.) e muito menos em sua concatenação imediata (nunca leia só um artigo, leia também os parágrafos e os demais artigos)". In: FERRAZ júNIOR, Tércio Sampaio. Introduçăo ao Estudo do Direito: Técnica, Decisão, Dominação. $4^{a}$ ed. São Paulo: atlas, 2003, p. 289.

4 BASTOS, Celso Ribeiro. Hermenêutica e Interpretação Constitucional. $3^{a}$ ed. São Paulo: Celso Bastos, 2002, p. 61.

3 BARROSO, Luís Roberto. Intefpretação e Aplicação da Constituiçâo. $3^{a}$ ed. São Pauto: Saraiva, 1999. p. $134 / 136$. 


\subsubsection{Método Teleológico}

Trata-se de interpretar e aplicar a norma tendo em vista a sua finalidade (mens legis), ou o seu espírito. Consiste em aplicar o raciocínio lógico-dedutivo ao dispositivo e, racionalmente, atribuir o sentido e alcance Que mais irá atingir a finalidade para a qual foi a lei criada ${ }^{44}$.

Segundo entendimento de Maximiliano, o método teleológico prepondera sobre os demais, seguindo-se a ele o método sistemático ${ }^{45}$.

O método teleológico é o único positivado no ordenamento jurídico. A Lei de Introdução ao Código Civil (LICC), Que disciplina algumas regras de aplicação temporal e espacial da lei, introduziu uma norma de cunho teleológico, em seu art. $5^{\circ}$, cujo dispositivo prevê: " $N a$ aplicação da lei, o juiz atenderá aos fins sociais a que ela se dirige $e$ às exigências do bem comum".

Cumpre ressaltar Que o Direito Constitucional, em sua definição essencial, apresentase como instrumento de realização dos valores supremos do ordenamento jurídico. A Constituição da República Federativa do Brasil, promulgada em 1988, em seu preâmbulo, destaca seis valores-fins do Estado Democrático, os Quais sejam, liberdade, igualdade, justiça, segurança, ordem e desenvolvimento (progresso). Todos esses valores podem ser sintetizados no ideal do bem comum (art. $3^{\circ}, \mathrm{IV} \mathrm{da} \mathrm{CF/88)} \mathrm{e} \mathrm{da} \mathrm{dignidade} \mathrm{da} \mathrm{pessoa} \mathrm{humana} \mathrm{(art.} 1^{\circ}$, III $\mathrm{da} \mathrm{CF} / 88)^{46}$. Assim, uma interpretação teleológica dos dispositivos da Constituição deve ter por fim a realização desses valores do Estado Democrático de Direito.

\section{UM ESTUDO SISTEMÁTICO DOS CÂNONES DE CARLOS MAXIMILIANO}

Maximiliano é autor de duas obras clássicas, nas Quais destacou as peculiaridades da Constituição frente as demais leis e comprovou a decorrente necessidade de fixação de regras de hermenêutica próprias à interpretação constitucional. Na primeira delas, Comentários à Constituição brasileira de 1891. Maximiliano aponta dezessete cânones de interpretação da Constituição. Trata-se de verdadeiros conselhos prudenciais para interpretação especificamente da lei fundamental, além de algumas orientaçōes ao intérprete constitucional para a correta utilização de regras de hermenêutica comuns à legislação ordinária ${ }^{47}$.

44 BARROSO, Luís Roberto. Interpretação e Aplicação da Constituição. $3^{a}$ ed. São Paulo: Saraiva, 1999. p. 137/138; BASTOS, Celso Ribeiro. Hermenêutica e Interpretaçăo Constitucional. $3^{\text {a }}$ ed. São Paulo: Celso Bastos, 2002, p. 60/61.

${ }^{45}$ MAXIMILIANO. Carlos. Hermenêutica e Aplicação do Direito. $19^{a} \mathrm{ed}$. Rio de Janeiro: Forense, 2005, p. 256.

Wh Conteúdo da Aula Inaugural do Curso de Especialização em Direito do Estado, UFRGS, turma 1/2004, ministrada pelo prof. Cezar Saldanha Souza lúnior, no dia 12/03/2004.

4 MAXIMILIANO, Carlos. Comentários à Constituição. la ed. p. 89/106. 
Em sua segunda obra, Hermenêutica e Ap/icação do Direito, o autor apurou seu estudo, passando a relacionar dezoito cânones de interpretação da Constituição. Estes são o produto da renovação dos tópicos já apresentados nos Comentários, desta feita reagrupados em doze cânones de interpretação, acrescidos de seiss novos conseh hos prudenciais, conforme se verá a seguir ${ }^{48}$.

Apesar da grande maioria das obras Que tratam da hermenêutica e interpretação da Constituição na atualidade estarem fundamentadas em várias das idéias de Maximiliano, sendo indiscutível a herança deixada pelo autor nessa área do conhecimento, não se tem notícia de um estudo sistemático sobre a validade e eficácia dos seus cânones de interpretação, diante do sistema jurídico atual. É essa a tarefa a Que se propõe a segunda parte do presente trabatho, na Qual se buscará sistematizar os cânones de Maximiliano, adequando-os e relacionando-os com os princípios constitucionais de interpretação mais aceitos pela doutrina contemporânea, principalmente tomando por base a obra de Luís Roberto Barroso, já citada ao longo do primeiro capítulo.

\subsection{Princípios da Interpretação Constitucional}

Ensina Humberto Ávila Que "os princípios são normas imediatamente finalísticas; primariamente prospectivas e com pretensão de complementariedade e de parcialidade, para cuja aplicação se demanda uma avaliação da correlação entre o estado de coisas a ser promovido e os efeitos decorrentes da conduta havida como necessária à sua promoção" 49 . São, portanto, verdadeiras normas de orientação teleológica, Que apontam uma direção a ser buscada, através de comportamentos necessários a essa realização. Dessa forma, "aos princípios cabe, além de uma ação imediata, Quando diretamente aplicáveis a determinada relação jurídica, uma outra, de natureza mediata, Que é a de funcionar como critério de interpretação e integração do Texto Constitucional" ${ }^{50}$, constituindo, nesse caso, o ponto de partida e objetivo final do intérprete.

Partindo desse conceito para uma análise mais ațenta dos cânones de Maximiliano, permite-se classificá-los e sistematizá-los como enunciados instrumentais de realização dos princípios constitucionais. Cumpre ressaltar Que esse conceito não corresponde à idéia desenvolvida por Celso Ribeiro Bastos, de "enunciados instrumentais da hermenêutica constitucional", na medida em Que esses últimos, conforme ressalta o autor, "são todos verdadeiras fórmulas hermenêuticas sem conteúdo axiológico, não fornecendo ao intérprete

\footnotetext{
49 Maximiliano. Carlos. Hermenêutica e Aplicaçăo do Direito. 19 ed. Rio de Janeiro: Forense, 2005 , p. $248 / 256$.

19 ÁVILA, Humberto. Teoria dos Princípios - da definiçăo à aplicação dos princípios jurídicos. $3^{a}$ ed. São Paulo: Malheiros, 2004, p. 70.

${ }^{50}$ BARROSO, Luís Roberto. Interpretação e Aplicação da Constituiçăo. $3^{a}$ ed. São Paulo: Saraiva, 1999. p. 147// 48.
} 
um sentido valorativo a ser seguido, senão Que fundamentam a opção por um ou outro sentido Que apresente como possível"51. Contrario sensu, os cânones de Maximiliano constituem enunciados prescritivos das condições eficazes da realização dos princípios constitucionais, produto de uma dedução lógica do sistema constitucional, restando evidente o seu conteúdo axiológico.

Assim é Que se apresentará a seguir uma visão nova e alternativa dos cânones de Maximiliano, através da Qual se pretende comprovar a implicação destes nos principais princípios contemporâneos da interpretação constitucional. A exposição Que segue levará en conta o rol apresentado em Hermenêutica e Aplicação do Direito, sem negligenciar a devida identificação ou comparação com os primeiros enunciados, Que constam dos Comentários à Constituição de 1891 . Ao final, se sustentará, de forma fundamentada, a invalidade de alguns dos enunciados os Quais se entende não terem sido acolhidos a partir da nova sistemática jurídica introduzida pela Constituição de 1988.

\subsubsection{Princípio da Supremacia da Constituição}

A Supremacia da Constituição é princípio Que deve nortear toda a interpretação de ato normativo. Decorre da superioridade hierárquica da Constituição frente às demais leis infra-constitucionais. Tem assento no princípio da Supremacia da Constituição o entendimento de Que todo ato jurídico ou manifestação de vontade incompatível com a Lei Maior deve ser declarado nulo ${ }^{52}$. Segundo esse princípio, a lei infra-constitucional deverá ser interpretada em conformidade com a Constituição, não se admitindo, por outro lado, Que as normas constitucionais sofram QualQuer influência por parte da legislação inferior ${ }^{53}$.

Destaca Luís Roberto Barroso Que a supremacia constitucional tem seu fundamento associado a dois conceitos, os Quais sejam: a diferença entre poder constituído e poder constituinte; e a diferença entre Constituições rígidas e flexíveis. Com efeito, năo há QualQuer limitação ao poder constituinte, sendo Que este não sofre restriçóes em razão do direito anterior. O poder constituído, por sua vez, submete-se a uma sistemática em Que as leis anteriores à nova Constituição e Que lhe forem incompativeis sempre considerar-se-ão revogadas; e aquelas supervinientes, cujo conteúdo contrarie a Constituição, nulas. Quanto

5 BASTOS, Celso Ribeiro. Hermenêutica e Interpretação Constitucional. $3^{a}$ ed. São Paulo: Celso Bastos, 2002, p. 181/182.

52 BARROSO, Luís Roberto. Interpretação e Aplicação da Constituição. $3^{a}$ ed. São Paulo: Saraiva, 1999. p. 156.

53 BASTOS, Celso Ribeiro. Hermenêutica e Interpretação Constitucional. $3^{\text {a }}$ ed. São Paulo: Celso Bastos, 2002. p. 172. O autor classifica a Supremacia da Constituiçăo como "postulado", os quais define como "... elementos Que são realmente pressupostos do sistema constitucional, a serem devidamente preservados e respeitados pela interpretaçäo (...). A interpretação, portanto, deverá, para se considerar como atividade válida, respeitá-los no seu todo, näo podendo proceder à escolha de um ou outro." 
à Questão da rigidez da Constituição, cumpre referir Que só há supremacia constitucional nos países que adotam Constituições rígidas, ou seja, naqueles países em que o processo de reforma da Constituição é mais complexo Que o processo legislativo infraconstitucional ${ }^{54}$.

Finalmente, cumpre ressaltar, Que é o judiciário que, com fundamento na Supremacia da Constituiçẫo, se encarrega do Controle de Constitucionalidade, não se admitindo que uma lei seja declarada inconstitucional por lei superveniente ${ }^{55}$.

Há três cânones de Maximiliano Que guardam relação direta com o princípio da Supremacia da Constituição, os Quais sejam:

V. Existe a inconstitucionalidade 'formal' alegável em todos os países e decorrente do fato de não ter o projeto de lei percorrido os trâmites regulares até a 'publicação' respectiva; e a 'intrínseca' ou 'substancial', relativa à incompatibilidade entre o estatuto ordinário e o supremo, da Qual os tribunais brasileiros, argentinos, mexicanos e norte-americanos tomam conhecimento, porém não pode ser ventilada nos pretórios europeus, em geral.

Esse enunciado foi introduzido em Hermenêutica e Aplicação do Direito, não havendo cânone correspondente na primeira obra de Maximiliano. Atualmente, Quase que a totalidade dos ordenamentos jurídicos realiza o controle de constitucionalidade substancial das leis infra-constitucionais, fundamentados no princípio da Supremacia da Constituição, sendo Que a maior parte dos países da Europa continental adotou a técnica de controle abstrato, com sistema de jurisdições distintas ${ }^{56}$.

XII. Quando o estatuto fundamental define as circunstâncias em Que um direito pode ser exercido, ou uma pena aplicada, esta especificação importa proibir implicitamente eualquer interferência legislativa para suịeitar o exercício do direito a condições novas ou estender a outros casos a penalidade ${ }^{57}$.

Esse enunciado reproduz o décimo primeiro cânone da obra Comentários à Constituição de $1891^{58}$. Trata-se de verdadeiro instrumental do princípio da Supremacia da Constituição, na medida em Que proibi expressamente Que a lei infra-constitucional exerça influência no alcance e eficácia das normas constitucionais.

54 BARROSO, Luís Roberto. Interpretação e Aplicação da Constituição. 3a ed. São Paulo: Saraiva, 1999 , P. $157 / 167$.

ss BARROSO, Luís Roberto. Interpretação e Aplicação da Constituiçăo. $3^{a}$ ed. São Paulo: Saraiva, 1999. p. 164.

56 Conforme aula de Direito Constitucional, ministrada pelo prof. Cezar Saldanha Souza lúnior, no curso de Especializaçăo em Direito do Estado, dia 10/09/04.

57 MAXIMiliano, Carlos. Hermenêutica e Aplicação do Direłto. $19^{a}$ ed. Rio de Janeiro: Forense, 2005, P. 255.

58 MAXIMILIANO, Carlos. Comentários à Constituição. $1^{2}$ ed. p. 98. 
XVII. A Constituição é a lei suprema do país; contra a sua letra, ou espírito, não prevalecem resoluções dos poderes federais, Constituições, decretos ou sentenças estaduais, nem tratados ou Quaisquer outros atos diplomáticos ${ }^{59}$.

Enunciado idêntico ao cânone XVI, de Comentários à Constituiçäo de $1891^{60}$, reforçando a percepção de Que desde sua primeira obra, Maximiliano procurou elaborar cânones de interpretação que realmente proporcionassem a realização do princípio da Supremacia da Constituição, princípio primeiro da interpretação constitucional.

XVIII. 'Interpretação autêntica' do texto constitucional só se obtém pelo processo estabelecido, no art. 217 de 1946, isto é, por meio de emenda ao estatuto básico. Nem sequer um ato da assembléia Que elaborou a Constituição ou a respectiva reforma teria o valor de exegese obrigatória. Podem-se decretar leis orgânicas para a execução completa do Código supremo; como, por exemplo, a relativa à organização da Justiça Nacional. Serão normas complementares, porém não 'interpretativas""6!

Em Comentários à Constituição de 1891, Maximiliano não formulou um enunciado específico sobre a interpretaçāo autêntica, limitando-se a conceituá-la. Percebe-se uma pequena mudança na abordagem do tema, na medida em naquela obra o autor ainda admitia Que a "lei directa ou indirectamente interpretativa tem algum peso e merece acatamento, mormente se é antiga; porém não firma exegese definitiva (...)" (sic), critério Que parece ter sido definitivamente afastado no segundo momento ${ }^{62}$. Parece claro que o enunciado em Questão instrumentaliza o princípio da Supremacia da Constituição, principalmente no aspecto ressaltado por Luís Roberto Barroso, da dicotomia entre Poder Constituinte e Poder Constituído. Somente o Poder Constituinte, em sua forma derivada, tem o poder de realizar a interpretação autêntica da Constituiçãa ${ }^{63}$.

\subsubsection{Princípio da Presunção de Constitucionalidade das leis e dos Atos do Poder Público}

Trata-se da presunção de Que todos os Poderes do Estado interpretam a Constituição, e de que seus órgãos sempre operam tendo em vista um fim comum, pautado nos valores

59 MAXIMILIANO, Carlos. Hermenêutica e Aplicação do Direito. $19^{a}$ ed. Rio de Janeiro: Forense, 2005, p. 256.

60 MAXIMLIIANO, Carlos. Comentários à Constituição. $1^{2}$ ed. p. 100.

6) MAXIMILIANO, Carlos. Hermenêutica e Aplicação do Direito, $19^{2}$ ed. Rio de Janeiro: Forense, 2005, p. 256.

62 MAXIMILIANO, Carlos. Comentários à Constituição. la ed. p. 102/106.

${ }^{63}$ Nesse mesmo sentido assevera Jorge Miranda: "De harmonia com os princípios, interpretação autêntica só pode ser feita por lei com força constitucional - ou seja, em Constituiçăo rígida, por lei decretada pelo processo peculiar de revisão, e não por lei ordinária (...) Tão-pouco é intef pretação autêntica a levada a cabo pelos órgãos de fiscalizaçăo de constitucionalidade, mesmo em sistema de concentração de competência". In: MIRANDA, Jorge. Manual de Direito Constitucional, v. II. p. 262/263. 
constitucionais, sendo válidos eneuanto tal. Nesse sentido, nenhum Poder pode interferir no âmbito das atribuiçốes do outro, para intervir nas Questões de sua "conveniência e oportunidade". Não obstante isso, reconhece a doutrina atual que cada um dos Poderes de Estado não exercem de forma exclusiva suas funções, mas como atividade preponderante. Além disso, cumpre ressaltar que a presunção insculpida no princípio em tela é iuris tantum. cabendo a declaração de inconstitucionalidade, uma vez que hạja prova nesse sentido ${ }^{64}$.

A presunção da constitucionalidade das leis e atos do Poder Público é, pois, um princípio funcional ao andamento do Estado. Todavia, deve-se dosar a sua interpretação e aplicação, pena de obter-se conseqüências desastrosas, de legitimação das razões de Estado contra os direitos fundamentais da cidadania. Assim, pode-se afirmar que, em um Estado Democrático de Direito, a validade destes atos é determinada e condicionada a outro princípio - o qual resgata o senso comum do direito que deve embasar a legitimidade dos atos de autoridade - conhecido entre nós, e positivado no ordenamento jurídico da Carta de 1988 , como princípio da moralidade.

Observe-se que o sistema de governo presidencialista e de tripartição dos poderes (executivo, legislativo e judiciário), influenciado por Montesquieu, foi adotado pela primeira vez no Brasil na Constituição de 1891 . Assim, pode-se compreender a razão pela Qual todos os cânones relacionados ao Princípio da Presunção de Constitucionalidade das Leis e dos Atos do Poder Público foram abordados por Maximiliano pela primeira vez na obra Hermenêtutica e Aplicação do Direito, pois ao tempo da publicaçăo dos Comentários à Constituição de 1891 , a separação dos poderes acabava de ser introduzida no sistema jurídico, não havendo ainda uma maior reflexão Quanto às suas implicaçôes ${ }^{65}$. Classificam-se como enunciados instrumentais do princípio de presunção de constitucionalidade, os seguintes:

11I. Todas as presunções militam a favor da validade de um ato, legislativo ou executivo; portanto, se a incompetência, a falta de jurisdição ou a inconstitucionalidade, em geral, não estão 'acima de toda dúvida' razoável, interpreta-se e resolve-se pela manutenção do deliberado por qualQuer dos três ramos em que se divide o Poder Público. Entre duas exegeses possíveis, prefere-se a Que não infirma o ato de autoridade. 'Oportet ut res plus valeat Quam pereat'. Os tribunais só declaram a inconstitucionalidade de leis Quando esta é evidente, não deixa margem a séria objeção em contrário. Portanto, se, entre duas interpretações mais ou menos defensáveis, entre duas correntes de idéias apoiadas por jurisconsultos de valor, o Congresso adotou uma, o seu ato prevalece. A bem da harmonia e do mútuo respeito Que devem reinar entre os poderes federais (ou estaduais), o fudiciário só faz uso da sua prerrogativa Quando o Congresso viola claramente ou deixa de aplicar o estatuto básico, e não Quando opta apenas por determinada 'interpretação' não de todo desarrazoada.

${ }^{6}$ BARROSO, Luís Roberto. Interpretação e Aplicação da Constituiçăo. $3^{3}$ ed. São Paulo: Saraiva, 1999 , p. $167 / 170$.

65 Nesse sentido: SOUZA JUNIOR, Cezar Sałdanha. Constituiçōes do Brasil. Porto Alegre: Sagra Luzzato, 2002, p. 41. 
Nesse enunciado, verifica-se claramente a ligação entre o princípio da presunção de constitucionalidade das leis e dos atos do poder público e o princípio geral da separação dos poderes. O sistema tripartite de separação dos poderes foi mantido pela Constituição de 1988, verificando-se, portanto, a validade desse cânone para a interpretação das normas do atual sistema jurídico.

IV. Sempre que for possivel sem fazer demasiada violência às palavras, interprete-se a linguagem da lei com reservas tais oue se torne constitucional a medida Que ela institui, ou disciplina ${ }^{66}$.

Esse enunciado não apenas tem validade para a interpretação da Constituição segundo o sistema jurídico atual, como foi praticamente reproduzido por Luís Roberto Barroso, Que o apresenta como a tradução prática do princípio da presunção de constitucionalidade doa atos do Poder Público, em regra sua Que segue: "havendo alguma interpretação possível Que permita afirmar-se a compatibilidade da norma com a Constituição, em meio a outras que carreavam para ela um juízo de invalidade, deve o intérprete optar pela interpretação legitimadora, mantendo o preceito em vigor ${ }^{* 67}$.

\subsubsection{Princípio da Interpretação Conforme a Constituição}

Consiste não apenas em um princípio de interpretaçāo constitucional, mas de verdadeiro mecanismo de controle de constitucionalidade, pois seus efeitos se equiparam aos de uma declaração de inconstitucionalidade de ato normativo (inconstitucionalidade parcial sem redução de texto). Consiste em buscar, dentre as diversas interpretações possíveis, aquela Que compatibiliza a lei com a Constituição ${ }^{68}$. Ao declarar Qual a interpretação do texto normativo Que é compatível com a lei fundamental, restringe-se a aplicação do dispositivo à interpretação declarada pelo tribunal, muito embora se mantenha a integridade do texto normativo ${ }^{6 \%}$.

th MAXIMILIANO, Carlos. Hermenêutica e Aplicaçăo do Direito. $19^{a}$ ed. Rio de Janeiro: Forense. 2005, p. $25 \mathrm{I}$.

G BARROSO, Luis Roberto. Interpretação e Aplicaçăo da Constituição. $3^{a}$ ed. São Paulo: Saraiva, 1999 , p. 171.

58 Em célebre passagem, ponderou Jorge Miranda: “a interpretação conforme à Constituiçãa năo consiste então lanto em escolher entre vários sentidos possíveis e normais de qualquer preceito o Que seja mais conforme com a Constituiçăo Quanto em discernir no linitte - na fronteira da inconstitucionalidade - um sentido que, embora não aparente ou näo decorrente de outros elementos de interpretação, é o sentido necessário e o Que se torna possive/ por virtude da força conformadora da Lei Fundamental". In: MIRANDA. Jorge. Manual de Direito Constitucional, v. ll. p. 264.

69 BARROSO, Luis Roberto. Interpretaçăo e Aplicação da Constituição. $3^{a}$ ed. São Paulo: Saraiva, 1999, p. $180 / 187$. 
Nesse sentido, pode-se perceber uma semelhança com o princípio da presunção de constitucionalidade das leiss e dos atos do Poder Púbico. Todavia, o Princípio da Interpretação Conforme apresenta outras dimensões, sintetizadas por Luís Roberto Barroso nos seguintes elementos ${ }^{70}$ :

1) Trata-se da escolha de uma interpretação da norma legal Que a mantenha em harmonia com a Constituição, em meio a outra ou outras possibilidades interpretativas Que o preceito admita; 2) Tal interpretação busca encontrar um sentido possível para a norma, Que não é o Que mais evidentemente resulta da leitura de seu texto; 3) Além da eleição de uma linha de interpretação, procede-se à exclusão expressa de outra ou outras interpretaçöes possiveis, Que conduziriam a resultado contrastante com a Constituição; 4) Por via de conseQüência, a interpretação conforme a Constituição não é mero preceito hermenêutico, mas, também, um mecanismo de controle de constitucionalidade pelo Qual se declara ilegítima uma determinada leitura da norma legal.

Pode-se afirmar Que relacionam-se com o Princípio da Interpretação Conforme à Constituição, os seguintes enunciados interpretativos de Maximiliano:

V. A constitucionalidade não pode decorrer só dos motivos da lei. Se o parlamento agiu por motivos reprovados ou incompativeis com o espírito do Código supremo, porém a lei não é, no texto, contrária ao estatuto básico, o tribunal abstém-se de a condenar ${ }^{71}$.

Esse cânone foi acrescentado pela obra Hermenêutica e Aplicação do Direito, sem correspondente nos Comentários à Constituição. Em havendo, pois, uma possibilidade de interpretação fundada nas razões do legislador (interpretação histórica), e sendo esta incompatível com a Constituiçăo, deverá ser afastada, declarando o tribunal uual a interpretação Que, sem alterar o texto normativo, pode ser atribuída ao dispositivo em conformidade à Constituiçăo, devendo esta prevalecer.

X. A Constituição aplica-se aos casos modernos, não previstos pelos que a elaboraram. Faz-se mister supor que os homens incumbidos da nobre tarefa "de distribuir os poderes emanados da soberania popular e de estabelecer preceitos para a perpétua segurança dos direitos da pessoa e da propriedade tiveram a sabedoria de adaptar a sua linguagem às emergências futuras, tanto como às presentes; de sorte Que as palavras apropriadas ao estado então existente da comunidade e ao mesmo tempo capazes de ser ampliadas de modo Que abranjam outras relaçôes mais óbvio e imediato sentido, se, de acordo com o

7) BARROSO, Luís Roberto. Interpretação e Aplicação da Constituiçâo. $3^{a}$ ed. São Paulo: Saraiva, 1999. p. $181 / 182$.

7 MAXIMILIANO, Carlos. Hermenêutica e Aplicação do Direito. $19^{\mathrm{a}}$ ed. Rio de Janeiro: Forense, 2005, p. $251 / 252$. 
obịetivo geral dos autores e os verdadeiros princípios do contexto, podem elas ser estendidas a diferentes relações e circunstâncias criadas por um estado aperfeiçoado de sociedade. Cumpre ao legislador e ao juizz, ao invés da ânsia de revelar inconstitucionalidades, mostrar solicitude no sentido de enquadrar na letra do texto antigo o instituto moderno. (...) A Constituição é a égide da paz, a garantia da ordem, sem a Qual não há progresso nem liberdade. Forçoso se the torna acompanhar a evolução, adaptar-se às circunstâncias imprevistas, vitoriosa em todas as vicissitudes, porém, Quanto possivel, inalterada na forma ${ }^{72}$.

Esse enunciado identifica-se com o oitavo cânone de Maximiliano em Comentários à Constituição de $1891^{73}$. Em outras palavras, a intenção do constituinte é aplicável na interpretação dos fatos novos, ou casos emergentes e imprevistos. Sendo possivel a construção de uma interpretação conforme a Constituição, Que se estenda aos fatos não previstos Quando da elaboração da lei, impõe-se a ad oção dessa interpretação.

\subsubsection{Princípio da Unidade da Constituição}

O princípio da Unidade da Constituição decorre da interpretação sistemática, método já abordado no presente trabalho. A Constituição é a norma fundamental que confere sistematicidade e unidade ao ordenamento. Além disso, há uma unidade interna da Constituição, Que determina Que a interpretação das normas consîtucionais não se dê de forma isolada, mas considerando-as pertencentes a um sistema jurídico únitário. Assim. todas as normas da Constituição devem ser harmonizadas e conciliadas, afastando-se as aparentes contradições. Não se pode afastar totalmente uma norma, invalidando-a para a aplicação plena de outra ${ }^{74}$.

São implicações do Princípio da Unidade da Constituição, embora com uma ênfase um pouco mais voltada à idéia de institucionalidade da Constituição, os seguintes cânones:

XI. Quando a Constituição confere poder geral ou prescreve dever franqueia também, implicitamente, todos os poderes particulares, necessários para o exercício de um, ou o cumprimento do outro. (...) A regra enunciada acima é completada por duas mais: a) Onde se mencionam as meios para o exercício de um poder outorgado, não será licito implicitamente admitir novos ou diferentes meios, sob o pretexto de serem mais eficazes ou convenientes; b) Onde um poder é conferido em termos gerais, interpreta-se como 'estendendo-se' de acordo com os mesmos termos, salvo se alguma clara 'restrição' for deduzivel do próprio contexto, por se achar ali expressa ou implícitars.

7 MAXIMILIANO, Carlos. Hermenêutica e Aplicação do Direito. $19^{\mathrm{a}}$ ed. Rio de laneiro: Forense, 2005, p. 253/254.

${ }^{3}$ MAXIMILIANO, Carlos. Comentários à Constituiçăo. Iª ed. p. 96.

74 BARROSO, Luís Roberto. Interpretação e Aplicação da Constituição. $3^{a}$ ed. São Paulo: Saraiva, 1999, p. $188 / 209$.

${ }^{75}$ MAXIMILIANO. Carlos. Hermenêutica e Aplicação do Direfto. $19^{\text {a }}$ ed. Rio de Janeiro: Forense, 2005, p. 254/255. 
Trata-se de regra mantida na segunda obra de Maximiliano (décimo cânone de Comentários à Constituição de 1891$)^{76}$. Tem-se, aQui, com toda clareza da impressionante síntese que integra o enunciado geral deste cânone, o antecedente doutrinário do conceito moderno de injunf̧̧ão, positivado pela Constituição de 1988. Postula o reconhecimento das implicações da generalidade, consistência e conseqüência da ordem constitucional - unidade da Constituiçăo. Guarda correspondência com o conceito da adjudicação no plano infraconstitucional.

XIV. Interpretam-se estritamente os dispositivos que instituem exceçóes às regras firmadas pela Constituição. (...) Na dúvida, siga-se a regra geral. Entretanto em Direito Público esse preceito não pode ser aplicado à risca: o 'fim' para Que foi inserto o artigo na lei, sobreleva a tudo. Não se admite interpretação estrita que entrave a realização plena do escopo visado pelo texto. Dentro da letra rigorosa dele procure-se o objetivo da norma suprema; seja este atingido, e será perfeita a exegese. (...) Quando as palavras forem suscetíveis de duas interpretaçôes, uma estrita, outra ampla, adotar-se-á aquela que for mais consentânea como fim transparente da norma positiva".

No enunciado supramencionado, o autor agrupou o décimo terceiro, décimo Quarto cânones de Maximiliano em Comentários à Constituição de $1891^{78}$. Esse cânone prescreve uma relação de implicação entre a realização do Princípio da Unidade da Constituição e a interpretação teleológica. Essa relação fol tratada pelo Tribunal Constitucional Federal alemão, na seguinte passagem: "o princípio mais importante de interpretação é o da unidade da Constituição enquanto unidade de um conjunto com sentido teleológico-lógico, já Que a essência da Constituição consiste em ser uma ordem unitária da vida política e social da comunidade estatal"79.

XV. Aplica-se à exegese constitucional o processo sistemático de Hermenêtica, $e$ também o 'teleológico', assegurada ao último a preponderância. Nesse terreno consideramse ainda de alta valia a 'jurisprudência', sobretudo a da Corte Suprema; os precedentes parlamentares; os fatores sociais e a 'apreciação do resultado, a Wertuteil', dos tudescos".

O décimo sétimo cânone de Maximiliano na obra Comentários à Constituição de 1891, referia-se apenas ao método teleológico, que considerava superior a todos os demais ${ }^{80}$.

* MAXIMiliano, Carlos. Comentários à Constituiçăo. $1^{2}$ ed. p. 97.

7 MAXIMILIANO, Carlos. Hermenêutica e Aplicação do Direito. 19a ed. Rio de Janeiro: Forense. 2005, p. 255/256.

${ }^{78}$ MAXIMILIANO, Carlos. Comentários à Constituiçăo. $\left.\right|^{\text {a }}$ ed. p. 99/100.

${ }^{79}$ BVerfGE, 19,206 (220) apud BARROSO, Luís Roberto. Interpretação e Aplicação da Constituição. $3^{a}$ ed. São Paulo: Saraiva, 1999, p. 189.

50 Esse cânone tinha a seguinte redação: "XVIl. A regra superior, Que sobrepuja a todas as outras e cuja inobservância é a causa de erros diarios nos pretorios e no Parlamento, consiste em indagar o 'fim da lei', a razăo de ser de una providência legisitiva, o objectivo que se teve em mira ao inserir um artigo, ou paragrapho, no texto constitucional" (sic). In: MAXIMILIANO, Carlos. Comentários à Constituição. la ed. p. $99 / 100$. 
O novo texto fala em processo sistemático, o Que revela o aprimoramento do pensamento do autor, relativamente à necessidade de unidade da Constituição.

$X V I . O$ brocardo - 'inclusio unius alterius est exclusio', como todo argumento 'a contrario', exige, talvez, ainda maior e mais discreta reserva da parte de Quem o empregue no Direito Constitucional, do Que se reclama em se tratando de Direito Privado. Nem sempre o fato de se mencionar um caso determinado obrigará a excluir todos os outros; nem tampouco a negativa a respeito de uma hipótese particular implicará a afirmativa tocante às demais"

Corresponde ao enunciado $\mathrm{XV}$ da primeira obra, cuja redação o autor sintetizou. Nesse cânone ressalta-se a idéia de sistematicidade e unidade do ordenamento. Assim, na análise de um dispositivo, seja ele enumerativo ou de inclusão de elementos, não se pode fazer uma interpretação isolada, devendo-se considerar o conjunto das normas constitucionais para determinar o alcance e as limitaçōes Que se operam sobre a norma.

\subsubsection{Princípio da (Máxima) Efetividade}

Trata-se de uma orientação ao intérprete no sentido de conferir a máxima efetividade às normas constitucionais no caso concreto, sem entretanto, alterar-lhes o conteúdo. Eficiência, conforme explica Luís Roberto Barroso, é um Quarto plano que se incorpora à teoria convencional dos atos jurídicos (existência, validade e eficácia) e que diz respeito à realizaçâo da norma. Afirma o autor Que "ela representa a materialização, no mundo dos fatos, dos preceitos legais e simboliza a aproximação, tão íntima Quanto possível, entre o dever-sernormativo e o serda realidade social" ${ }^{81}$.

A aplicação do Princípio da Efetividade não pode descuidar da Unidade Constitucional, na medida em Que a otimização de uma de suas normas poderia implicar na invalidade de outras. Assim, na interpretação de uma norma, deve o intérprete buscar a máxima efetividade de toda a Constituição.

É enunciado instrumental do Princípio da Efetividade:

1. O Código fundamental tanto prevê no presente como prepara para o futuro. Por isso, ao invés de se ater a uma técnica interpretativa exigente e estreita, procura-se atingir um sentido que torna efetivos e eficientes os grandes principios de governo, e não o que os contrarie ou reduza a inocuidade. Bem observa Story; "O governo é uma coisa prática. Feita para a felicidade do governo humano, enão destinada a propiciar um espetáculo de uniformidade Que satisfaça os planos de politicos visionários. A tarefa dos que são chamados a exercê-ló é

81 BARROSO, Luís Roberto. Interpretação e Aplicação da Constituição. $3^{a}$ ed. Săo Paulo: Saraiva, 1999. P. 236. 
dispor, providenciar, decidir; e näo debater; seria pobre compensaçâo haver alguém triunfado numa disputa, enquanto perdiamos um império; termos reduzido a migalhas um poder e ao mesmo tempo destruído a República".

Esse enunciado não encontra correspondência com qualQuer dos cânones enunciados na obra Comentários à Constituição de 1891 . O cânone ainda é válido, desde Que observada uma importante ressalva. Senão vejamos.

A Constituição da República Federativa do Brasil (CF/88), seguindo a tendência Que se verificou nas Constituições européias do segundo pós guerra, é um referencial supremo de valores, tendo adotado como valores essenciais do nosso sistema constitucional: a liberdade, igualdade, justiça, segurança, ordem e desenvolvimento (bem-estar), Que constituem condições genéricas de realização do bem comum. O bem comum, fim último da Constituição, nada mais é do que todas as condições que devem ser oferecidas à pessoa humana para que ela própria se realize e realize a sua felicidade ${ }^{82}$. A Constituição Federal de 1988 tem, portanto, por prioridade primeira a dignidade da pessoa humana.

Do exposto, resulta Que a aplicaçăo do enunciado em exame deve ser feita adaptandoo à nova realidade do sistema jurídico-constitucional, de modo que se atinja a máxima efetividade da norma sempre Que ocorrer a realização do bem comum, afastando-se a predominância dos interesses do governo sobre os direitos fundamentais da pessoa humana.

\subsection{Do uso do Costume}

Trata-se o costume de um mecanismo de integração da Constituição ${ }^{83}$. A integração é o processo de preenchimento de lacunas, ou vazios normativos. Difere, portanto, da interpretação, na medida em Que esta pressupōe a existência de uma norma a ser aplicada ao caso concreto, constituindo a atividade de compreensão e atribuição do sentido e alcance dessa norma. Tendo em vista a idéia de sistema jurídico, onde se pretende que todos os casos tenham solução possivel no ordenamento, a integração surge como um processo de "preenchimento de eventuais vazios normativos" ${ }^{44}$, Que utiliza-se do costume e da analogia, para encontrar o direito aplicável ao caso concreto ${ }^{85}$.

* Cfme. aula de Direito Constitucional, ministrada pelo Professor Cezar Saldanha Souza lúnior, no curso de Especialização em Direito do Estado da UFRGS, dia 14/05/04.

83 "Nesse sentido, o reconhecimento dos costumes como fonte os torna, na omissăo da lei, meio de integração praeter legem. Obviamente, como meio integrador, o costume ocupa os vazios do ordenamento legal e não do ordenamento global, ao Qual pertencem também as normas consuetudinárias. Ou seja, se há norma costumeira, não há lacuna, mas pode haver omissão de norma legal. É o sentido da integração praeter legem." In: FERRAZ IÚNIOR, Tércio Sampaio. Introdução ao Estudo do Direito: Técnica, Declsão, Dominaçăo. 4a ed. São Paulo: Atlas, 2003, p. 304.

84 BARROSO. Luís Roberto. Interpretação e Aplicação da Constituiçâ̆o. $3^{a}$ ed. São Paulo: Saraiva, 1999. p. 139.

85 Nesse sentido: BARROSO, Luís Roberto. Interpretação e Aplicação da Constiluiçãa. $3^{a}$ ed. Săo Paulo: Saraiva, 1999, p. 142: "A verdade, todavia, é que o costume constitucional tem duplo e relevante 
Maximiliano elaborou cânones de interpretação que se apoiam no costume, adotando uma metodologia mais usual aos países de common law. Entretanto, considerando-se que o sistema jurídico brasileiro tem gradativamente fortalecido o uso do costume - prova disso é o próprio papel Que vem sendo assumido pela jurisprudência no ordenamento pátrio - podese afirmar que o costume, a comparação e a historicidade dos fatos jurídicos configuram padrōes de interpretação válidos. Assim, conclui-se pela aplicabilidade dos seguintes cânones de Maximiliano. de caráter essencialmente histórico e consuetudinário:

11. Forte é a presunção de constitucionalidade de um ato ou de uma interpretação, Quando datam de grande número de anos, sobretudo se foram contemporâneos da época em Que a lei fundamental foi votada. "Minime sunt mutanda, Que interpretationem certam semper habuerunt". Todavia o princípio não é absoluto. O estatuto ordinário, embora contemporâneo do Código supremo, não the pode revogar o texto, destruir o sentido óbvio, estreitar os limites verdadeiros, nem alargar as fronteiras naturais $(\ldots)^{86}$.

Identifica-se com o primeiro cânone de Maximiliano em Comentários à Constituição de 1981. Esse enunciado instrumentaliza o costume como método de interpretação, mas de forma ponderada e limitada ao princípio da Supremacia da Constituição.

XIII. A prática constitucional longa e uniformemente aceita pelo Poder Legislativo, ou pelo Executivo, tem mais valor para o intérprete do que as especulaçôes engenhosas dos espíritos concentrados. (...) Entretanto a exegese adotada pelas Câmaras, ou pelo Executivo, não influi 'peremptoriamente' nas decisôes do /udiciário, senão nos casos politicicos ${ }^{87}$.

Cânone acrescentado pelo autor, não havendo correspondente nos Comentários à Constituição. Inspirou-se o autor essencialmente no direito americano, onde há o entendimento, consagrado pela Suprema Corte, no sentido de que excluem-se dos litígios de índole constitucional as Questões políticas ${ }^{88}$.

VIII. O elemento histórico auxilia a exegese do Código básico, mantida a cautela de só atribuir aos debates no seio da Constituinte o valor relativo que se deve dar, em geral, aos 'trabalhos parlamentares'. A história da Constituição e a de cada um dos seus dispositivos

papel, Quer para a integraçăo da ordem constiucional em caso de lacuna, Quer como fonte auxiliar da interpretaçäo constitucional. O costume, a prática constitucional, é um importante ponto de referência na passagem do campo normativo para o terreno da realidade"; BASTOS, Celso Ribeiro. Hermenêutica e interpretaçăo Constitucional. $3^{a}$ ed. São Paulo: Celso Bastos, 2002, p. 74: "A própria Constituiçăa da República pode fazer apelo a formas de integração, tais como, o costume constitucional, a Declaraçäo Universal dos Direitos do Homen, e a remissão do tema à lei ordinária".

${ }^{36}$ MAXimillaNO, Carlos. Hermenêutica e Aplicação do Direito. 19a ed. Rio de laneiro: Forense, 2005, p. 250.

8 MAXIMLliano, Carlos. Hermenêutica e Aplicaçăo do Direito. $19^{a}$ ed. Rio de Janeiro: Forense, 2005, p. 255.

${ }^{*}$ BARROSO. Luís Roberto. Interpretação e Aplicação da Constituição. $3^{a}$ ed. Săo Paulo: Saraiva, 1999, p. 173. 
contribuem para se interpretar o texto respectivo. (...) Trata-se de compreender o estatuto brasileiro à luz da História e da evolução dos princípios republicanos; examine-se quais idélas dominantes na época do advento do novo regime, o que se pretendeu manter, o que se preferiu derrocar. Compare-se o texto vigente com a Constituição Imperial e a dos estados Unidos, não olvidando que o espírito destas duas, bem como os casos da "Common Law e Equity", colhidos em clássicos e brilhantes comentários, guiam o escrupuloso intérprete da lei básica de 24 de fevereiro de 1981. É de rigoro recurso aos 'Anais' e a outros documentos contemporâneos, a fim de apurar Qualera, na época da Constituinte, a significaçâo verdadeira e geralmente aceita dos termos técnicos encontrados no texto. (grifou-se)

Esse enunciado resultou do agrupamento e sintetização dos cânones II, III e IV, da obra Comentários à Constituiçâo de 1988, Que tratam, essenciaimente, do método de interpretação histórica. Tem validade no sistema jurídico atual, ressalvando-se o trecho grifado, cuja formulaçāo deve-se ao fato Que a Constituição de 1891 consistiu na verdade em uma cópia da Constituição americana, adaptada pela Assembléia Constituinte para entrar em vigor no Brasil. Conforme análise feita por Roberto Rosas, "não apenas a Constituição de 1891 era inadeouada à tradição brasileira, mas também não foi uma cópia fiel da Constituiç̧ão norte-americana. Pior do Que isto, copiou o modelo, mas fez uma nova versão deste, uma versão feita por políticos não habituados à tradição anglo-saxônica Que guiou a Constituição estadunidense" ${ }^{89}$. Muito embora o sistema jurídico-constitucional instaurado a partir de 1988 tenha internalizado diversos institutos do direito americano, não o fez com a intensidade do Constituinte de 1891 .

IX. Quando a nova Constituição mantém, em alguns dos seus artigos, a mesma linguagem da antiga, presume-se que se pretendeu não mudar a lei nesse particular, e a outra continua em vigor, isto é, aplica-se à atual a interpretação aceita para a anterior. O texto do Código fundamental do Império e os respectivos comentários facilitam a exegese do estatuto republicano, assim como o Direito inglês é invocado pelos publicistas dos Estados Unidos. Ainda mais: os direitos assegurados pela Constituição antiga prevalecem, na vigência da nova, nos pontos em que esta não revogou aquela.

O enunciado acima corresponde ao nono cânone da obra Comentários à Constituição de 1891. Conforme supramencionado, trata-se da tendência de fortalecimento da jurisprudência, manifestação do costume dos pretórios, na interpretação dos novos dispositivos da Constituição. A última parte do enunciado refere-se a um aspecto oue parece um pouco esquecido pela doutrina contemporânea. Trata-se da manutenção dos direitos fundamentais, assegurados pela Constituição anterior, Quando não revogados pela nova Constituição. Assemelhamse ao Que chamamos de vedação de retrocesso, mas se opera em nível constitucional.

89 ROSAS, Roberto apud SOUZA IUNIOR, Cezar Saldanha. Constituiçōes do Brasil. Porto Alegre: Sagfa Luzzato, 2002, p. 44. 


\subsection{Cânones não Recepcionados pela Constituição de 1988}

Dos dezoito cânones de interprețçāo da Constituição, Que constaram da obra Hermenêutica e Interpretação da Constituição, cuja primeira edição data de 1924, apenas um deles é totalmente inaplicável segundo o atual sistema jurídico, o Qual seja:

VII. Embora as expressões nas leìs suprema sejam, mais do Que nas ordinárias, vazadas em linguagem técnica, nem por isso entenderão aquelas como escritas em estilo arrevesado e difícil, inacessível à maioria, e, sim, em termos claros, precisos. Não se resolve contra a letra expressa da Constituição, baseado no elemento histórico ou no chamado Direito natural. Cumpre-se o Que ressalta dos termos da norma suprema, salvo o caso de forte presunção em contrário: às vezes o próprio contexto o oferece fundamento para o restringir, distender ou, simplesmente, determinar. Não podem os tribunais declarar inexistente um decreto, legislativo ou executivo, apenas por ser contrário aos princípios da justiça, às noções fundamentais do Direito: é de rigor Que viole a Constituição, implícita ou explícitamente. Em todo caso, do exposto se não conclui que o só elemento filológico baste para dar verdadeiro sentido e alcance das disposiçôes escritas.

Esse enunciado agrupou o Qujinto e sétimo cânones da obra Comentários à Constituição de 1891. No atual sistema constitucional, os princípios gerais de direito são cogentes em nível hierárquico igual ao da própria Constituição, razão pela Qual é inconstitucional o enunciado supramencionado (art. $5^{\circ}, \S 2^{\circ}$ da Constituição Federal/88).

\section{CONCLUSÃo}

A interpretação é atividade de fundamental importância para a realização do direito. Tem papel essencial, não apenas na Questão da justificação das decisões judiciais, exigência introduzida a partir do séc. XVIII na maioria dos regimes constitucionais, mas, principalmente, na concretização de um sistema jurídico fundado em valores. É por meio da atividade interpretativa Que poderá o jurista aplicar a lei de uma maneira comprometida com os princípios fundamentais do ordenamento jurídico. Eé a interpretação dos textos normativos Que leva o cientista do direito a sustentar novos posicionamentos, influenciando a disciplina das Questões jurídicas mais relevantes e, em última análise, inovando no sistema jurídico em busca do seu contínuo aperfeiçoamento.

A interpretação das leis deve sempre levar em consideração a unidade do sistema jurídico, que é ponto de convergência dos direitos fundamentais em tem seu final último na 
Constituição. Todas as regras, princípios e mesmo os enunciados elaborados pelos cientistas do direito, com base no critério da prudência - aos quais denominamos cânones - devem respeitar, por conseguinte, a supremacia da Constituição.

Essa hermenêutica tem implicação, não apenas às leis infraconstitucionais, como também aos próprios dispositivos constitucionais, Que precisam ser aplicados em harmonia com todas as demais normas da Constituição.

A partir dessa visão, foram apontadas no presente trabalho algumas diretrizes à atividade interpretativa constitucional, fundamentadas nas obras Comentários à Constituição de 1891 e Hermenêutica e Interpretação do Direito, de Carlos Maximiliano. Seus enunciados, também chamados cânones, têm fundamento na prudência, valor importante a ser resgatado pelo direito, Que deveria sempre nortear a atividade do jurista, são ainda, em sua quase totalidade, válidos nos dias de hoje.

No decorrer do trabalho, pôde-se perceber que alguns desses cânones foram positivados pela Lei Maior, e muitos se identificam com princípios trabalhados atualmente pela doutrina, ainda que de forma desapercebida e um tanto quanto desordenada, resultando daí Que os mesmos foram não apenas acolhidos pelo sistema jurídico-constitucional introduzido pela Constituição de 1988, como alguns deles inspiram e se concretizam na hermenêutica constitucional contemporânea.

A abordagem feita no presente trabalho não tem por pretensão esgotar todas as facetas da riqueza doutrinária Que cedo emergiu nos Comentários de Carlos Maximiliano, à primeira Constituição republicana do Brasil. Trata-se de uma visão dos cânones sob novo ângulo, ainda não trabalhado pela doutrina e Que se espera possa contribuir com o resgate e a valorização da obra do eminente jurista no debate acadêmico.

\section{REFERÊNCIAS BIBLIOGRÁFICAS}

AYDOS, Eduardo Dutra. A Planície de Alétheia - Contribuição para a (re)construção teórica de uma epistemologia de síntese. Porto Alegre: UFRGS, 2002.

AYDOS, Elena de Lemos Pinto. Aspectos Atuais do Direito de Marca: A regulamentação da Marca e sua Proteção Através das Técnicas Diferenciadas de Tutela. Trabałho de conclusão de Curso de Graduação. PUCRS: Porto Alegre, 2003.

ÁVILA, Humberto. Teoria dos Princípios - da definição à aplicação dos princípios jurídicos. $3^{3} \mathrm{ed}$. São Paulo: Malheiros, 2004.

BARROSO, Luís Roberto. Interpretação e Aplicação da Constituição. $3^{a}$ ed. São Paulo: Saraiva, 1999.

BASTOS, Celso Ribeiro. Hermenêutica e Interpretação Constitucional. $3^{a}$ ed. São Paulo: Celso Bastos, 2002.

BONAVIDES, Paulo. Direito Constitucional. Rio de Janeiro: Forense, 1980. 
CARVAl.HO, Paulo de Barros. Curso de Direito Tributário. $16^{\text {a }}$ ed. São Paulo: Saraiva, 2004.

FERRAZ IÚNIOR, Tércio Sampaio. Introdução ao Estudo do Direito: Técnica, Decisão, Dominação. $4^{\mathrm{a}}$ ed. São Paulo: atlas, 2003.

IUSTINIANO. Digesto de Justiniano, livro I. Tradução de Hélcio Maciel França Madeira. $2^{\text {a }}$ ed. São Paulo: RT, 2000.

MAXIMILIANO, Carlos. Hermenêutica e Aplicação do Direito. 19a ed. Rio de laneiro: Forense, 2005.

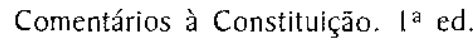

MIRANDA, lorge. Manual de Direito Constitucional. 2. ed. Coimbra: Coimbra Ed, 1982-1988. $2 \mathrm{v}$.

MONTESQUiEu, Do Espírito das Leis. Coleção Obra Prima de Cada Autor. São Paulo: Martin Claret, 2002.

NETO, Cláudio Pereira de Souza. A Interpretação Constitucional Contemporânea entre o Construtivismo e o Pragmatismo. In: MAIA, A. C.; MELO, C.C.; CITTADINO. G; POGREBINSCHI, T. (Org.). Perspectivas Atuais da Filosofia do Direito. Rio de Janeiro: Lumen furis, 2005.

POGREBINSCHI. Thamy. Problema da Justificação no Direito: Algumas Notas sobre Argumentação e interpretação. In: MAIA, A. C.; MELO, C.C.; CITTADINO. G; POGREBINSCHI, T. (Org.). Perspectivas Atuais da Filosofia do Direito. Rio de laneiro: Lumen luris, 2005.

ROBLES, Gregório. O Direito Como Texto: Quatro estudos se teoria comunicacional do direito. Barueri, SP: Manole, 2005.

PEIRCE, Charles S. Semiótica. São Paulo: Perspectiva, 1977.

SANTI, Eurico Marcos Diniz de. (Coord.). Curso de Especialização em Direito Tributário - Homenagen a Paulo de Barros Carvalho. Rio de laneiro: Forense, 2004.

SOUZA JUNIOR, Cezar Saldanha. Constituições do Brasil. Porto Alegre: Sagra Luzzato, 2002. 